\title{
Integrating Politeness Principles and Strategies in Counselling Technique: A Phenomenological Study
}

\author{
Syafryadin Syafryadin ${ }^{1} *$ \\ Universitas Bengkulu, Indonesia \\ *Corresponding Author \\ Email: syafryadin@unib.ac.id
}

DOI: http://dx.doi.org/10.18326/jopr.v3i2.147-159

Copyright (C) the Author (s)

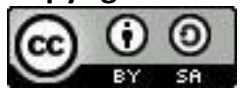

This work is licensed under a Creative Commons Attribution-ShareAlike 4.0 International License.

How to Cite: Syafryadin, S. (2021). Integrating Politeness Principles and Strategies in Counselling Technique: A Phenomenological Study. Journal of Pragmatics Research, 3(2). doi: http://dx.doi.org/10.18326/jopr.v3i2.147-159

\footnotetext{
Submission

Track:

Received:

17-06-2021

Final Revision:

03-09-2021

Available online:

06-09-2021

\begin{abstract}
Politeness is an important academic topic. An action must be taken to prevent rudeness. As a result, this study investigates how counseling techniques can modify students' behavior to be more courteous by implementing politeness tactics and concepts. Furthermore, the purpose of this study is to determine why counseling strategies may alter students' perspectives. The research was conducted using a phenomenological study using an observation checklist and interview guideline. The instruments were triangulated for validity. Data collection, data condensation, data display, and conclusion were all used in the data analysis. The findings revealed that Counselling Technique could have an impact on the outcome. The findings revealed that Counselling Technique had the ability to change students' conduct to become more polite. The students used negative politeness methods to consult with the instructors during its execution. Furthermore, students used all of the politeness standards, including the tact principle, generosity principle, modesty principle, approval principle, compassion principle, and agreement principle. In summary, the counseling strategy could be employed to help pupils with their behavioral issues
\end{abstract}

Keywords: Politeness principles, strategies; counselling technique, Phenomenological study 


\section{INTRODUCTION}

Politeness is still an important issue of research since 10 or 15 years ago. Politeness is a form of good attitude to apply in our life. However, it can cause a conflict if the people broke the rule of politeness. According to Brown and Levinson (1987), politeness is a fundamental thing in using a language based on social context that used to maintain the success of communication in a society. Besides, politeness could guide the positive character of the speaker in behaving toward someone because it shows the respect between communicant and communicator.

The problems that occurred in a society whether in the world and in Indonesia, many students still disobey politeness rules in interacting to other people or older person, especially this issue happens between students to the teacher or students to lecturers. Based on the observation, many students did not know how to be polite to the lecturer when texting to the lecturer. In this part, students did impoliteness texting to lecturers, such as deciding time by her or himself, force lecturer to consult and did not write the name. One of the alternative solutions to change the behaviour of the students is Counselling because counselling technique is a technique that can be used to assist the students become better understanding about the theory and practice (Stone, 2005). The purpose of counselling technique is to give awareness about core values that lead the students to the real actions or alter the students' attitude. This counselling technique is expected to cope the students' problems in terms of politeness.

Many researchers had conducted the research on politeness topic. Those researches could be classified into three main themes namely politeness types, politeness principle and the effect of culture and linguistic choice on politeness. Some researchers aimed to analyse the types of politeness strategies whether in oral or written form, such as speech, novel, movie and teaching process. The results showed that politeness strategies occurred in those forms namely positive politeness, negative politeness, bald on record, off-record politeness strategies.

However the dominant part is depended on the form whether written or spoken (Safitri, Mujiono, Herawati, 2015; Ryabova, 2015; Rosari, 2016; Nailah, 2016; Eshghinejad \& Moini, 2016; Kravchenk \& Pasternak, 2016; Marlina \& Selfia, 2016; Syah, et al., 2017; Kamlasi, 2017; Agbaglo, 2017; Putri, et al., 2018; Pratiwi, et al., 2018; Marlina \& Sibarani, 2018; Nur \& Rosa, 2019; Meiratnasari, et al., 2019; Mahmud, 2019; Kuzhevskaya, 2019).

Other studies identified politeness principles in their research. Their findings were almost same about obey the rules of politeness and break the rules of politeness principle. For example, in their research occurred politeness principle, such as Generosity, modesty, Approbation, agreement, sympathy, and tact principle), but it also broke the principles (Elmianvar \& Kheirabadi, 2013; Karim, 2016; Liu, 2017; Samsi, 2018; Mufliharsi \& Pratiwi, 2019; Ruantika, 2019; Rosyida, et al., 2019).

Furthermore, there were researchers who wanted know the effect of culture and linguistic choice on politeness strategy. The results showed that culture, linguistic choice has an impact on 
the way of people to another people, and it influences the level of politeness and its strategy (Ghounane, Mortad, Rabahi, 2017; Fitriah \& Hidayat, 2018).

Referring to problems and relevant studies, the current research has a distinction from the previous ones because the current study wants to rise the issue of impoliteness that happens to the students by training or mentoring the students to be more polite to whom they speak. Surely, this research is opposite to the previous studies that only identified and analysed the types of politeness strategies and principle and effect to the culture. Therefore, this research aims to portrait the students' and lecturers' counselling technique experience on politeness during journal consultation. The research questions are (1) How counselling technique change students' impoliteness to be politeness in doing journal consultation? (2) Why counselling technique could change students' attitude to be politeness in doing journal consultation?

\section{Politeness}

Politeness is one of the pragmatics aspects that show the attitude of the speaker. Moreover, politeness will guarantee the relationship among speakers because it will keep the relation among interlocutors. Politeness is in relation to the social lives. It will also save the speakers' face (Yule, 1996). Thus, in my poin of view, politeness is a attitude that can be done by speaker or listener. This will lead the speaker or listener to have social value in the society. It means that it will keep the relationship among speakers.

\section{Types of Politeness Strategies}

According to Yule (1996), there are several types of politeness. Those are positive politeness, negative politeness, bald on record and off the record. Firstly, A Positive politeness strategy is one of the politeness strategies that lead the speaker to achieve a common goal, even friendship via expressions. In this strategy, the speakers' relation is close. See the example 1.

Example 1

A: How about letting me use your rule?

B: Hey, my bro, I'd appreciate it if you'd let me use your rule?

Secondly, negative politeness strategy is one of politeness strategies that show the save the face of the speaker. In this strategy, there is a gap between the speaker 1 and speaker 2 . The example can be seen in example 2.

Example 2,

A: Could you lend me a ruler?

B: I am sorry to bother you, but could I ask you for a ruler or something?

Off record is one of the strategies in which the statements are not directly addressed to other speakers. The example can be seen in example 3. 
Example 3,

A: Uh, I forgot my ruler

B: hmmmm, I wonder where I put my pen.

Bald on record is one of the strategies that the statement of the speaker is directly addressed to another speaker. The example can be seen in example 4.

Example 4,

A: Give me a ruler

B: Lend me a ruler

\section{Politeness principle}

According to Leech in Chaer (2010), there are six politeness principles. Those are tact, generosity, approbation, modesty, agreement, sympathy. The first, Tact principle is one of the principles that show the wise of speaker to say and give benefits to the speaker. For example, you know I really do think you ought to sell that old car. It's costing more and more money in repairs and it uses ip far too much fuel. The second, generosity principle is one of the principles that minimize benefit to self and maximize cost to self. For example, it is not my business really, but you look so much nicer in the green hat than in the pink one. If I were you, I would buy that one. The third, modesty principle refers to appreciation. It means that the speaker tends to show respect by saying praises to the communicant. According to Watts (2003), modesty can be defined as one of the principles that minimize dispraise to others. For example, Dear my brother, I would like to thank to you because you have helped me. The fourth, modesty is almost the same as approbation. In this principle, the speaker reduces dispraise of self and maximizes praise of self. For example, Well done! What a wonderful painting! I hope I can do it the same. The fifth, agreement principle is a principle that reduces disagreement between self and others. For example, I know we haven't always agreed in the past and I don't want to claim that the government acted in any other way than we would have done in power, but we believe the affair was essentially mismanaged from the outset. The sixth, sympathy is a principle that minimizes the antipathy and increase the sympathy to others. For example, Despite very serious disagreements with you on a technical level, we have done our best to coordinate our efforts in reaching an agreement, but have so far not been able to find any common ground. In short, those politeness principles were important to be known and implemented by speakers. It is because if we have known the politeness principle, it will cause good relationship between one speaker to another speaker.

\section{Counseling technique}

Counseling technique is a technique that assists someone to solve their problems. Stone (2005: 85) defined counseling technique as an ongoing process for development. He also added that counseling is one of the elements of the coaching, where coaching as means to increase the 
performance of the people. The communication process is one of the keys of the counseling because the communication as tool for the counselor and client to negotiate. In this case, it can be analogy for student and lecturer. There are three practices that becomes the communication as means of counseling. Those are (1) communicate openly, directly, and honestly, (2) practice active listening, (3) probe and question. The first, communicate openly, directly and honestly means that everything must be communicated by the lecturer to students if the students have problem. The second, practice active listening refer to creating small discussion with the students in which the lecturer listen the students' problems and vice versa the students listen to the lecturer advices. The third, probe and question mean that the lecturer as a counselor (in this context) investigated the student by asking the open ended question to find out the information of the problem and what is really happening to the student.

\section{RESEARCH METHOD}

Qualitative research is a research type that explains about the phenomenon and phenomenological study is one of kinds of it. Thus, a Phenomenological study with observation checklist and interview guideline was employed to conduct the research. The phenomenology study is a research design that describes and interprets an experience by determining the meaning of the experience by the people who have participated in the event (Ary, Jacobs, Sorensen, \& Razavieh, 2010: 471).

There were two lecturers and fifteen students who became participants of this study because only two lecturers who guided students to do consultation about journal and only 15 students who wanted to submit their final paper to Journal in period of September in one of the journals in English Education Study program, University of Bengkulu. Moreover, the sampling technique used purposive sampling because the researcher aimed at looking the experience of lecturers in changing the students' impoliteness to be more polite during consultation.

The research ethic was undertaken by getting permission to the head of study program. Surely, the validation of interview guideline and observation checklist was undertaken by doing triangulation to enhance the trustworthiness. The instruments were made based on the indicator of politeness principle and strategies. The procedures of data collection were (1) Contacting the head of study program and participants of the research to participate, (2) gathering the data through an observation, (3) interviewing several students about the counseling technique to change their behaviors, (4) interviewing lecturers in relation to the topic of the research, (4) Achieving the data of interview and observation.

The qualitative data were analyzed by using a theory adopted from miles, Huberman, Saldana (2014). The steps of data analysis were data collection, data condensation, data display, and conclusion. The first, data collection refers to the data were obtained by the researcher from 
instruments. The second, data condensation means that the data gathered were selected and focused based on the research objectives.

Hence, the researcher opted the transcript of the interview and observation sheet that relates to answer the research questions. The third, data display is a data that been organized and displayed to support the research. In this stage, instruments results (interview transcript and observation checklist) were deeply analyzed to strengthen the findings of the research. The fourth step is a conclusion. The researcher concluded the data analysis from the data reduction until data display. This stage was essential to know whether the data analysis had answered the research questions or not.

\section{RESULTS AND DISCUSSION}

\section{Results}

\section{How counseling technique change students' impoliteness to be politeness in doing journal consultation?}

To answer the first research question, the researcher used an observation checklist and interview. Based on the observation checklist for lecturer and students, the researcher found that lecturers had used a counseling technique in improving the students' politeness. In the first meeting of the consultation about English journal, the lecturer did not use a counseling technique; they just check the template and the content of journal directly. After looking at the students' behavior that did not show the politeness to the lecturers, the lecturers altered their technique during consultation, the lecturers did not only mentor, but also counsel the students. Referring to observation checklist, lecturers explained the theory of principle of politeness and politeness strategies. Hence, students knew the theory. The students' responses were good. The students understood and implemented the theory in the next meeting. The students' texted the lecturers in politeness way. The screen can be seen in following figure 1 and Figure 2.

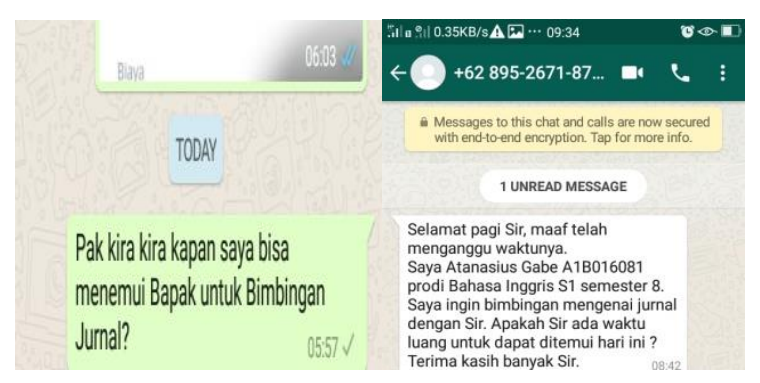

Figure 1. Before using counseling 


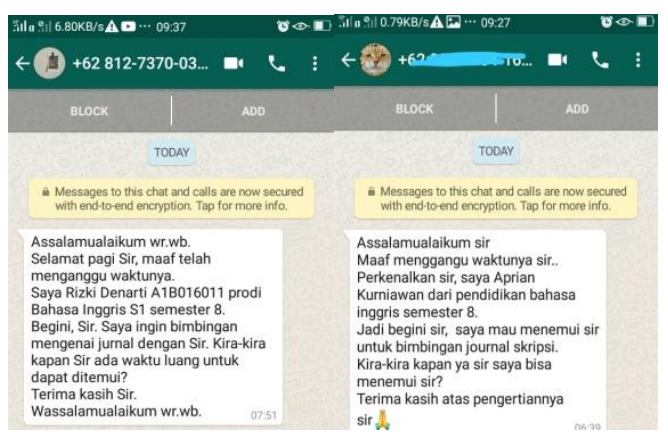

Figure 2. After using counseling

Based on figure 1, it shows the student did not indicate the politeness when texting to the lecturer because the students did not greet, did not write the name, write thanks. As a result, the lecturer did not know who texted. Directly, it broke the politeness principle. Moreover, in the second screenshot, the student directly decided the time to consult about journal. This may be impolite because the student seems to force the lecturer to meet, even though the student write their name, greet, and say thank.

However, in figure 2, the students had changed their behavior after the lecturers gave counseling to the students. The lecturers informed polite principle and politeness strategies, such as positive, negative, bald on record, and off the record politeness strategies. Thus, students could understand the politeness. In figure 2, it can be seen that, the students used politeness strategy namely negative politeness, for instance, the students greet (Assalamualaikum), the content of the message is good, write "thanks" to the lecturers (terima kasih atas pengertiannya).

Referring to the observation checklist, the lecturers had applied the counseling technique, and the students also had implemented the politeness principle and politeness strategies during the consultation to the lecturers. The students used a negative politeness strategy to consult with the lecturers. Moreover, the students followed politeness principles, such as tact principle, generosity principle, modesty principle, approbiation principal, sympathy and agreement principle. For more details, the examples of students' and lecturers' conversation can be seen in table 1 .

Table 1. Conversation between Lecturer and students

\begin{tabular}{|l|l|l|}
\hline Politeness principles & Conversations & Accepted/ broken \\
\hline Tact Principle & Conversation between lecturer (L) and & The principle Accepted \\
student (S) & S: Pak, saya sudah merevisi yang kemarin. & \\
Ini pak hasil revisinya mohon untuk dicek & \\
kembali. & L: Okay. Ini sudah bagus, namun ada \\
beberapa hal yang harus diperbaiki lag & \\
bagian findings and references. \\
Based on the conversation, the students \\
followed the tact principle because the \\
student did not cut the lecturer' explanation \\
and still silent to hear it. The student is also \\
polite.
\end{tabular}




\begin{tabular}{|c|c|c|}
\hline Modesty principle & $\begin{array}{l}\text { L: Okay. Kamu harus revisi dulu lagi ya } \\
\text { beberapa catatan sir. } \\
\text { S: Ya Sir. Terima kasih. Saya akan segera } \\
\text { merevisi. } \\
\text { Based on the conversation, students showed } \\
\text { their modesty to the lecturer by saying thank } \\
\text { to the lecturer. }\end{array}$ & The principle accepted \\
\hline $\begin{array}{l}\text { Approbiation } \\
\text { principle }\end{array}$ & $\begin{array}{l}\text { L: ...ini kamu revisinya banyak. Kamu harus } \\
\text { kerja keras untuk perbaiki background } \\
\text { sampai references. } \\
\text { S: Iya sir. Maaf sir. Insya Allah saya akan } \\
\text { memperbaikinya } \\
\text { Referring to the conversation, student } \\
\text { received the correction or feedback with } \\
\text { good attitude. He did not reject the comment } \\
\text { of the lecturer }\end{array}$ & Principle accepted \\
\hline Generosity principle & $\begin{array}{l}\text { S: Assalamualikum } \\
\text { L: Waalaikumsalam } \\
\text { S: How are you,sir? } \\
\text { L: I am fine. What about you? } \\
\text { S: I am fine too sir. } \\
\text { L: Have a sit! } \\
\text { S: Thank you sir. Sir, I am Andini. I have } \\
\text { revised my article sir. } \\
\text { Based on the conversation, } \\
\text { The students showed the generosity by } \\
\text { saying "Assalamualaikum", thank you". The } \\
\text { lecturer also showed it by responses in polite } \\
\text { way and asks the student to sit. }\end{array}$ & Principle accepted \\
\hline Agreement principle & $\begin{array}{l}\text { L: Kamu harus revisi lagi artikel kamu ini, } \\
\text { research methodology, findings, } \\
\text { discussionnya masih banyak yang kurang. } \\
\text { Bisa ya? } \\
\text { S: Siap sir. Bisa. } \\
\text { L: Good. } \\
\text { S: Sir, nnt misalnya kalau saya udah revisi, } \\
\text { kira kira kapan saya bisa dating lagi sir } \\
\text { untuk revisi } \\
\text { L: Hmm.. besok bisa jam } 10 \text { ke kantor ya. } \\
\text { S: SIap sir. Terima kasih sir. } \\
\text { The conversation showed the accepted } \\
\text { agreement principle because there is } \\
\text { agreement between lecturer and students in } \\
\text { terms of revision and schedule in doing } \\
\text { consultation. }\end{array}$ & Principle accepted \\
\hline
\end{tabular}

Why counseling technique could change students' attitude to be politeness in doing journal consultation?

To answer research question number 2, the researcher used an interview to several students to know their reasons about counseling technique that can change their attitudes to be more 
politeness. For more details, the interview transcript and the analysis could be seen in excerpt below.

\section{Excerpt 1}

Researcher : Why counseling technique could change your behavior to be more polite?

Students 1 : Hmm...I think this counseling is very useful for me to change behavior because counseling technique could give me a lesson about how to behave to the lecturer, and other people.

Referring to excerpt 1, the student's reason is the counseling technique could change their behavior because counseling is very useful for him/her and counseling can give a lesson about behavior

\section{Excerpt 2}

Researcher : Why counseling technique could change your behavior to be more polite?

Students 2 :The reason eee the counseling technique could change my behavior because in counseling technique, the lecturer guide me to know the good role model in behaving.

Based on excerpt 2, the reason of student 2 shows the benefits of counseling technique where, the student is guided by the lecture in good behavior. Besides, the lecturer also becomes the role of students in behaving during a journal consultation.

\section{Excerpt 3}

Researcher : Why counseling technique could change your behavior to be more polite?

Students 3 : I think counseling technique helps me a lot about how to behave to the lecturer or another person because in counseling technique, the lecturer explains to me about the importance of politeness.

In excerpt 3, the reason of the student 3 is a counseling technique that could help the student how to be polite to the lecturer. Besides, in counseling technique, the lectuer tells about the importance of politeness.

Excerpt 4

Researcher : Why counseling technique could change your behavior to be more polite?

Students 3 : Eeee because in counseling technique gives a lesson for me about the way we behave to another people. And if I do mistakes in behaving, the lecturer as a counselor could correct my attitude because attitude is more important than intelligence.

In excerpt, the reason is almost the same as the other students; this counseling technique has a benefit to treat the student to be more behave. 


\section{Excerpt 5}

Researcher : Why counseling technique could change your behavior to be more polite?

Students 3 : Because counseling technique could teach me the way I behave to other people.

In excerpt 5, the student's reason is that counseling technique could teach and help the student to behave to other people.

\section{DISCUSSION}

Based on the findings, the discussion of this study comprised of the counselling technique that change students' impoliteness to be politeness in doing journal consultation and the reason counselling technique change students' attitude to be more politeness in doing journal consultation. Firstly, the implementation of counselling technique to the students during journal consultation could give an impact on students' behaviour. In counselling technique, the students are taught about politeness theory that involves politeness principle and strategy. The students implemented the politeness strategies in doing journal consultation. The students used negative politeness strategies because students did a consultation to the lecturer, where the lecturer is the older person than the students.

Besides, the students respected the lecturer during consultation from the beginning until the end of the consultation. The use of negative politeness is in line with the theory by Yule (1996) who stated that negative politeness is one of the strategies where there is a gap among speakers. In the other words, the gap means that the speakers have different status namely as a lecturer and a student. Moreover, this finding is supported by relevant studies which researched on politeness. The results of their research showed that dominant strategy used is a negative politeness because negative politeness strategy because this strategy could give more respect to the people (Marlina \& Sibarani, 2018; Nur \& Rosa, 2019; Meiratnasari, et al., 2019; Mahmud, 2019; Kuzhevskaya, 2019). Another first finding was the obey of politeness principle by the students. In this aspect, students have applied the politeness principle in doing conversation to the lecturers, hence the flow of the conversation and politeness happened among speakers. This politeness principle is important to keep the relationship among interlocutors. As Ruantika (2019) stressed that politeness principle must be obeyed to have a good attitude in doing a conversation. By knowing the politeness principle, the students know the rules in behaving especially speaking to another speaker.

Secondly, the reason counselling technique could change the students' behaviour. Based on the interview, most of the students stated that counselling technique could alter their attitude to be more polite because in counselling technique, they got many inputs about rules of politeness and politeness strategies. Moreover, the lecturers always gave good role model for the students. It means that the lecturers showed good example in behaving to other people either in terms of speaking or gestures. Thus, the students could imitate the lecturers' good attitude. This finding is 
in line with Stone (2005) who stated that counseling technique is a technique that could help the people to change their behavior.

\section{CONCLUSION}

Overall, Counselling Technique could influence the students' behaviour to be more polite. In its implementation, the students had applied negative politeness strategies to consult with the lecturers. Moreover, students also employed all principles of politeness namely tact principle, generosity principle, modesty principle, approbations principal, sympathy and agreement principle. Furthermore, the students had strong reason why the counselling technique could change their attitude. It is because Counselling technique could guide and assist them being more polite person. Consequently, their personalities become better.

\section{REFERENCES}

Agbaglo, E. (2017). The use of politeness strategies in the analysis and discussion sections of English research articles. Research on Humanities and Social Sciences. 7(9), 30-42.

Ary, D., Jacobs, L.C., Sorensen, C. Razavieh, A. (2010). Introduction to Research in Education. Australia: Wadsworth Cengage Learning.

Brown, P., \& Levinson, S. (1978). Universals of Language Usages: Politeness Phenomena; in: Esther Goody (ed.), Questions and Politeness Strategies in Social Interaction. Cambridge: Cambridge University Press, 56-311.

Chaer, A. (2010). Kesantunan Berbahasa. Jakarta: Rineka Cipta.

Elmianvari, A., \& Kheirabadi, R. (2013). The study of EFL students' requests based on the politeness theory. Journal of Language Teaching and Research. 4(2), 375-385.

Eshghinejad, S., \& Moini, R. M. (2016). Politeness strategies used in text messaging: Pragmatic competence in an asymmetrical power relation of teacher-student. SAGE Open. 1-13.

Fitriah., \& Hidayat, D.H. (2018). Politeness: Cultural dimensions of linguistic choice. Indonesian Journal of English Education (IJEE). 5(1), 26-34.

Ghounane, N., Mortad, I.S., Rabahi, H. (2017). Politeness strategies employed towards linguistic taboos in Tlemcen society. Open Journal of Modern Linguistics, 7, 217-228.

Kamlasi, I. (2017). The positive politeness in conversation performed by the students of English study program of Timor University. METATHESIS. 1(2), 68-81.

Karim, A.S. (2016). Analysis on cooperative principle and politeness principle in guest complaining at X Hotel in Kuta Bali. RETORIKA: Jurnal ilmu bahasa. 2(2), 394-408.

Kravchenk, N.K., \& Pasternak, T.A. (2016). Politeness Strategies via Speech acts and Conversational Implicatures. Science and Education a New Dimension, Philology. IV(25), 60-63. 
Kuzhevskaya, E. (2019). Politeness strategies in business English course. Training, Language and Culture. 3(4), 36-46.

Liu, L. (2017). Application of cooperative principle and politeness principle in class questionanswer process. Theory and Practice in Language Studies. 7(7), 563-569.

Mahmud, M. (2019). The use of politeness strategies in the classroom context by English university students. Indonesian Journal of Applied Linguistics. 8(3), 597-606.

Marlina, L., \& Selfia, M. (2016). An analysis of politeness strategies used by Deddy Corbuzier in Hitam Putih Talk show. E-Journal of English Language \& Literature. 5(1), 19-28.

Meiratnasari, A., Wijayanto, A., Suparno. (2019). An analysis of politeness strategies in Indonesian English textbooks. ELS-JISH ELS Journal on Interdisciplinary Studies on Humanities. 2(4), 529-540.

Marlina, L., \& Sibarani, J.G. (2018). Politeness strategy used in republican debate by Donald Trump. E-Journal of English Language \& Literature. 7(4), 1.

Miles, M.B., Huberman, A.M., Saldana, J. (2014). Qualitative data analysis, a. Methods sourcebook, Edition 3. USA: Sage Publications

Mufliharsi, R., \& Pratiwi, H.A. (2019). Politeness principle: President Joko Widodo's speech act in video blog. BAHTERA: Jurnal Pendidikan Bahasa dan Sastra. 18(1), 79-92.

Nailah. (2016). Politeness strategies used by the main characters in "Transformer: Age of extinction movie”. Unpublished Thesis. English Letters and Language Department, Faculty of Humanities UIN Malang.

Nur, I.M., \& Rosa, R.N. (2019). An analysis politeness strategies in the directive uttered by characters in Big Hero 6 Movie. E-Journal of English Language and Literature. 8(3), 69-75.

Pratiwi, et al. (2018). Brown and Levinson's politeness strategies on apologizing expression of the princess diaries (2001) the movie: A discourse analysis. Jurnal Edukasi. V(1), 24-26.

Putri, D.J., Ermanto., Manaf, N.A., Abdurrahman.(2018). Speech act politeness in asking and answering questions in discussion of students at madrasah tsanawiyah negeri. Advances in Social Science, Education, and Humanities. 301, 354-360.

Rosari, M. (2016). Politeness strategies applied by the characters of the Great Debates movie. LLT Journal. 19 (1), 19-33.

Rosyida, A., et al. (2019). An analysis on politeness principle in Kung Fu Panda 1 the movie. Journal of Pragmatic Research. 1(1), pp.23-29.

Ruantika, R.A. (2019). An analysis of politeness strategies and cooperative principle used by the characters of Coco Movie. IOSR International of Research and Method in Education (IOSRJRME). 9(4), 55-59.

Ryabova, M. (2015). Politeness strategy in everyday communication. Procedia: Social and Behavioural Sciences. 206, 90-95. 
Safitri, F.L.N., Mujiono., Herawati, S. (2015). A study on politeness strategies of characters in the big wedding movie directed by Justin Zackham. Jurnal Ilmiah Bahasa \& Sastra. 2(2), 93107.

Samsi, Y.S. (2018). Investigating speech act and politeness in classroom interaction. UPI $2^{\text {nd }}$ International Conference on Language, Literature, Culture and Education (ICOLLITE). 257, 128-131.

Stone, F.M. (2005). Couching, counseling and mentorin: How to choose \& use the right technique to boost employee performance. New York: AMACOM.

Syah, N.A., Djatmika., Sumarlam. (2017). The politeness of directive speech acts in Satu Jam Lebih Dekat on TV One (pragmatic approach). Prasasti: Journal of Linguistics, 2(2), 300315.

Watts, R. J. (2003). Politeness. New York: Cambridge University Press. 